\title{
Teaching/Learning Strategies in Context of Education 4.0
}

\author{
Irina Golitsyna*,1, Farid Eminov², Bulat Eminov ${ }^{3}$ \\ ${ }^{1}$ Institute of Information Technology and Intelligent Systems, Kazan (Volga) Federal University, Kazan, 420008, Russian Federation \\ ${ }^{2}$ Automated Information Processing Systems and Control Department, Kazan National Research Technical University, Kazan,420111, \\ Russian Federation
}

${ }^{3}$ GBU PDD, Kazan, 420059, Russian Federation

\begin{tabular}{l} 
A R T I C L E I N F O \\
\hline Article history: \\
Received: 22 December, 2020 \\
Accepted: 22 February, 2021 \\
Online: 17 March, 2021 \\
\hline Keywords: \\
Education 4.0 \\
educational technologies \\
training of IT-specialists \\
educational content \\
enterprise infrastructure \\
\hline
\end{tabular}

\begin{abstract}
A B S T R A C T
Coronavirus pandemic and transition to distance learning have significantly accelerated the introduction of Education 3.0 - 4.0 technologies into traditional educational process. This paper discusses questions of training of IT- specialists in context of Education 4.0. Based on our experience, approaches to the organization of the educational process of ITstudents are considered. It is discussed, what elements of mobile learning, self-directed learning and informal learning are used by students. Informal learning in traditional educational process of IT- students is considered in such aspects as the source of knowledge, personalization, teaching/learning methods. The paper discusses a stage-bystage approach to formation of interdisciplinary educational content for IT-students. In conclusion, the strategies of teaching / learning of Education 4.0, useful for forming of competencies for Industry 4.0, are discussed.
\end{abstract}

\section{Introduction}

This paper is an extension of work originally presented on the 12th International Conference on Developments in eSystems Engineering (DeSE)[1].

Pandemic changed traditional forms of educational process and accelerated introduction of e-learning technologies of Education 3.0 - 4.0. Education 3.0 is web-based, student-centered learning. Education 4.0 places the learner at the center of the educational ecosystem. Education 4.0 refers to the Industry 4.0 curricula. "The term ' 4.0 ' is related to the new technical possibilities for which the concept of E-learning or digital learning already exists”[2].

The infrastructure of Education 3.0-4.0 forms on the base of mobile technologies, social software, cloud services, online educational resources, mass open online courses (MOOC) [1]. Education 4.0 summarizes every problem that arises in $21 \mathrm{st}$ century education. This can be educational content, didactics, or methods [2].

Next aspects are important in advanced Training 4.0: learning on-demand, online learning in web-communities, learning

${ }^{*}$ Corresponding Author: Irina Golitsyna, 35, Kremlevskaya Street, Kazan, 420008, Russia, (843) 221-34-33 \& Irina.Golitsyna@gmail.com regardless of time and place, mobile learning, self-organized and self-directed learning, a combination of different training methods and environments [2].

In this paper we consider strategies of teaching/learning and formation of educational content for IT-students in the Education 4.0 concept, based on our teaching experience.

The hypothesis of the research is: in order to develop the competencies of modern specialists, it is necessary to keep in mind the experience of using modern technologies by students, regardless of teachers; on the other hand, it is necessary to develop approaches to the educational content formation and teaching/ learning methods, taking into account the needs of modern industry.

Based on the survey of IT students, we shown that they independently use such the Education 4.0 technologies as mobile learning, self-directed learning and informal learning.

In conditions of the Industry 4.0 development, specialists must be ready for successful professional activities in a modern enterprise. As one of possible approaches to the educational content formation for IT students we propose the interdisciplinary 
approach based on the infocommunication infrastructure of an enterprise.

\section{Literature review}

The main goal of Industry 4.0 is to improve the efficiency and flexibility of enterprises so that they can adapt to the demands of the future. Technologies such as robotics, simulation, horizontal and vertical integration systems., the industrial internet of things, cybersecurity, cloud computing, additive manufacturing, augmented reality, big data and analytics can be used to achieve this goal [3]. All these technologies allow enterprises to use the vast amount of information to make more effective decisions. The development of digital technologies increases the importance of specialists who are able to interact in network environment and maintain complex production [4], [5]. In conditions of rapid development of technologies, a professional of Industry 4.0 must constantly learn from other professionals with different education and experience [3]. An important task for modern education is to identify the competencies necessary for future specialists to effectively enter the labor market [3], [6], [7]. Knowledge and competencies required for Industry 4.0 include: information technologies, software engineering, programming, data communications and computer networks, interfaces, network protocols, internet of things, systems understanding, cloud solutions, sensors and electronics, lean production. Among the competencies that new participants must have in order to implement Industry 4.0 are the following: technical skills, process understanding, understanding IT security.

Real-world experience show that the most corresponding skills and competencies are 21 st century skills or competencies for lifelong learning. They contribute to the continuous and progressive self-renewing and self-regulation, and can be transferred and directly applicable in various social and professional business environments [8].

The concept of Industry 4.0 legitimizes changes in the production sphere, in the labor market, but, basically, in all spheres of society [9], including education. Education 4.0 combines various methods and approaches by which institutions of higher education align their services and curricula to prepare future graduates for work [10]. An obvious idea of universities 4.0 is: they must develop the 'learning to learn' meta-competence. This meta-competence seems to be the key to a good job and a good life; this can lead to optimization of a person and overcoming his obsolescence [11]. At the same time, Education 4.0 places more emphasis on self-directed learning using technology [12].

Education 4.0 is education for Industry 4.0, on the other hand, its infrastructure is the natural development of the infrastructure of e-learning technologies Education 1.0 - 3.0.

The formation of the Education 4.0 infrastructure leads to development of e-learning technologies as shown in Table 1 [13].

Table 1: Educational Technologies in Education 4.0

\begin{tabular}{|l|l|l|}
\hline Characteristics & Education 4.0 & $\begin{array}{l}\text { Educational } \\
\text { technologies }\end{array}$ \\
\hline $\begin{array}{l}\text { Technological } \\
\text { platform }\end{array}$ & Mobile devices & $\begin{array}{l}\text { Mobile } \\
\text { learning. }\end{array}$ \\
\hline
\end{tabular}

\begin{tabular}{|l|l|l|}
\hline Software & $\begin{array}{l}\text { LMS (Learning } \\
\text { Management Systems), } \\
\text { MOOCs (Massive } \\
\text { Open Online Courses), } \\
\text { social software, cloud } \\
\text { resources, professional } \\
\text { software, open } \\
\text { electronic platforms for } \\
\text { online interaction }\end{array}$ & $\begin{array}{l}\text { Eistance } \\
\text { learning. } \\
\text { self- } \\
\text { organizational } \\
\text { students in } \\
\text { social } \\
\text { networks. }\end{array}$ \\
\hline $\begin{array}{l}\text { Lellaboration of } \\
\text { teachers and students } \\
\text { in electronic } \\
\text { information- } \\
\text { educational } \\
\text { environment (EIEE) }\end{array}$ & $\begin{array}{l}\text { Flexible } \\
\text { learning. } \\
\text { Blended } \\
\text { learning. }\end{array}$ \\
\hline $\begin{array}{l}\text { Methods of } \\
\text { teaching/learning }\end{array}$ & $\begin{array}{l}\text { Productive, in context } \\
\text { of EIEE }\end{array}$ & $\begin{array}{l}\text { Self-directed } \\
\text { learning. } \\
\text { Informal } \\
\text { learning. }\end{array}$ \\
\hline
\end{tabular}

\section{Methodology}

The purpose of this study is to identify the factors contributing to the development of key competencies of IT specialists in the context of the development of Education 4.0 technologies. We consider strategies of teaching/learning in context of Education 4.0 in the next aspects:

1. Educational technologies, that develop independently of educational institutions on the basis of the Education 4.0 infrastructure, are reviewed based on literature and our experience in training of specialists of bachelor programs 09.03.02 Information systems and technologies and 09.03.03 Applied Informatics.

Quantitative descriptive research as full-time classroom survey was made to determine what elements of mobile learning, self-education and informal learning are used by students in the traditional educational process. We made a survey of students of bachelor programs 09.03.02 Information systems and technologies and 09.03.03 Applied Informatics of Kazan Federal University in 2018. In the questioning took part 96 students of 3 rd and 4th years of study. From this survey we have considered such aspects, as sources of knowledge, forms of learning, self-directed learning. Questions in the questionnaire were identified and based on the literature review and the expert opinions. Our colleagues, the teachers involved in the training of IT specialists acted as experts. The survey results are presented in the form of histograms. Most of these histograms have been discussed at conferences [1], [14], or published in the paper [15]. The histograms show the ratio of positive answers on the proposed questions to the total number of respondents as a percentage.

2. We propose approach to formation of educational content for IT-students on the base of the enterprise infocommunication infrastructure. This approach has developed in our experience in training of students of bachelor programs 09.03.02 Information systems and technologies and 09.03.03 Applied Informatics in Kazan Federal University and in Kazan National Research Technical University for several years. This approach has been discussed at conferences [1], [16]. The educational content and 
methodological support of disciplines within the framework of the declared approach has been published in the number of educational and methodological manuals, e.g.[17]-[19].

Feedback has come also from personal conversations with students and discussions at the alumni meetings of Kazan National Research Technical University over the years.

\section{Results and Discussions}

\subsection{Strategies of Teaching/ Learning}

We consider below, how the teaching / learning strategies outlined in Table 1, are implemented in the traditional educational process of IT professionals. We used the mentioned above survey of students of bachelor programs 09.03.02 Information systems and technologies and 09.03.03 Applied Informatics.

\subsubsection{Educational Technologies of Education 4.0 in Traditional Educational Process}

Mobile learning is being developed on the basis of mobile devices and technological communication channels. Immediate switch of educational institutions on distant learning stimulated to use of mobile devices in the pandemic context.

According to [20], the mobility concepts in higher education can be divided into three important directions: mobility of technology, mobility of learners and mobility of learning. Mobile devices are used by students for educational communication, for example, to discuss educational issues and exchange ideas with classmates. In general, most students think that mobile devices can help them to learn.

We can see from histogram in Figure 1 students' answers to the question: "What forms of mobile internet do you use during educational process?".

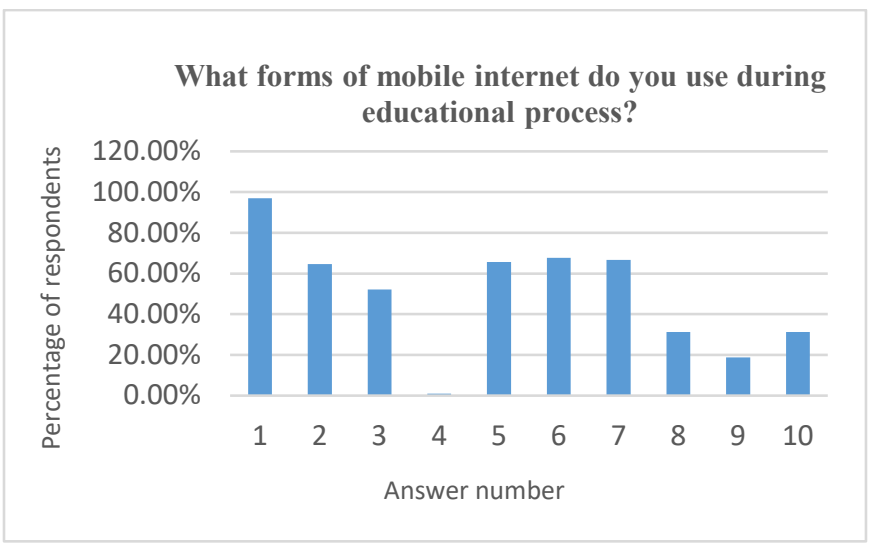

Figure 1: Students' answers to the question: "What forms of mobile Internet do you use during educational process?"

Answer options:

[1] Search engines

[2] Wikipedia

[3] Cloud storage resources

[4] Mobile access to the university library

[5] Electronic textbooks

[6] Social networks

[7] Messengers

[8] Specialized programming forums

[9] Integrated development environments (IDE)

[10] Mathematical problem-solving resources

www.astesj.com
Survey shows, that students actively use mobile access in the educational process to available web services, such as search engines, Wikipedia, cloud storage resources, electronic textbooks, social networks and messengers. This infrastructure of mobile learning has been developed independently of educational institutions, and teachers have been able to use the ready-made infrastructure in the educational process in the current conditions. Students use the virtual environment for access to educational resources from mobile devices, thereby using the opportunities of mobile learning.

Students form a mobile personal learning environment and become full participants in the formation of EIEE of educational institusions in accordance with the modern education development trends.

Distance learning has become an only possible form of education in the context of coronavirus pandemic. This situation accelerated the introduction of e-learning technologies into the traditional educational process. Along with LMS and MOOC, open electronic platforms for online interaction (such as Microsoft Teams, Google Zoom etc.) have been widely used in current conditions.

Flexible learning refers to the use of online learning in a traditional learning process. IT- students actively use the electronic professional environment for learning and solving assigned tasks, therefore, technology of flexible learning can be effectively used for their education. Students use web-resources in educational activities, form a personal-oriented EIEE. Teachers receive the opportunities to develop new teaching methods, to personalize learning and organize students' independent work [21].

Blended learning is developing based on the use of e-learning elements in a traditional educational process [22]. The concept of blended learning also involves learning in a workplace, which allows teachers to master and use vocational training technologies.

Self-directed learning. As noted above, self-directed learning is one of the key competencies for Industry 4.0.

We can see from histogram in Figure 2 students' answers to the question: "Are you engaged in self-directed learning?".

We can conclude, that students are independent in self-directed learning, they actively use specialized books and textbooks and programming forums, learn on educational online resources, some of them attend educational courses.

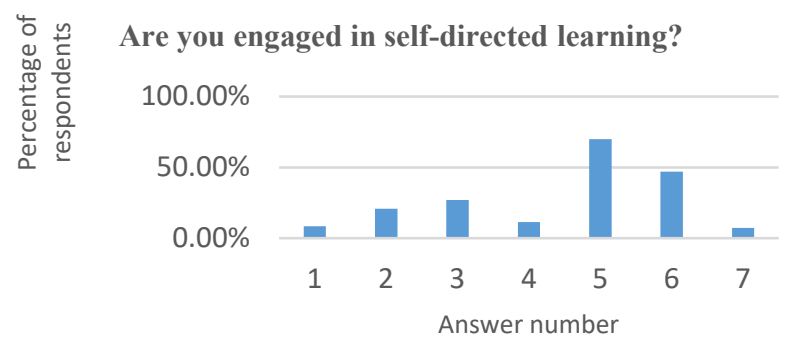

Figure 2: Students' answers to the question: "Are you engaged in self-directed learning?"

Answer options:

[1] No

[2] I attend educational courses

[3] I learn on educational online resources 
[4] I use professional forums

[5] I read specialized books and textbooks

[6] I use programming forums

[7] Other

Students widely use web-resources for self-directed learning and for solving academic tasks. Table 2 shows web- resources that IT-students use in various types of educational activities to form professional competencies [1].

Table 2: Learning Activities of Students with Web-resources

\begin{tabular}{|l|l|}
\hline Learning activities & Web-resources \\
\hline $\begin{array}{l}\text { Educational } \\
\text { communications of } \\
\text { students and teachers }\end{array}$ & $\begin{array}{l}\text { E-mail, social networks, } \\
\text { cloud services }\end{array}$ \\
\hline Information search & Search engines \\
\hline $\begin{array}{l}\text { Studying of new } \\
\text { educational content }\end{array}$ & $\begin{array}{l}\text { Electronic textbooks, } \\
\text { educational resources, } \\
\text { Wiki -resources }\end{array}$ \\
\hline Solving mathematical tasks & $\begin{array}{l}\text { Mathematical online resources, } \\
\text { online calculators, computer } \\
\text { algebra systems }\end{array}$ \\
\hline Programming & $\begin{array}{l}\text { IDE, programming forums, } \\
\text { online professional } \\
\text { communities }\end{array}$ \\
\hline
\end{tabular}

The use of web resources in traditional educational process and in self-directed learning leads to formation of personal learning environment for each student. This environment is a continuation and extension of EIEE of educational institutions, allowing teachers and students to develop teaching / learning strategies in context of requirements of Education 4.0.

\subsubsection{Informal Learning}

As noted above, competencies of lifelong learning are the most relevant competencies for Industry 4.0. Lifelong learning includes formal, nonformal, and informal learning. The role of informal learning has increased in current conditions. Informal learning is an unstructured learning in a family, community or/in the workplace. Mastering of informal learning experiences prepares students for lifelong learning. Development of this competence is important for professional activity of specialists in conditions of the fourth industrial revolution.

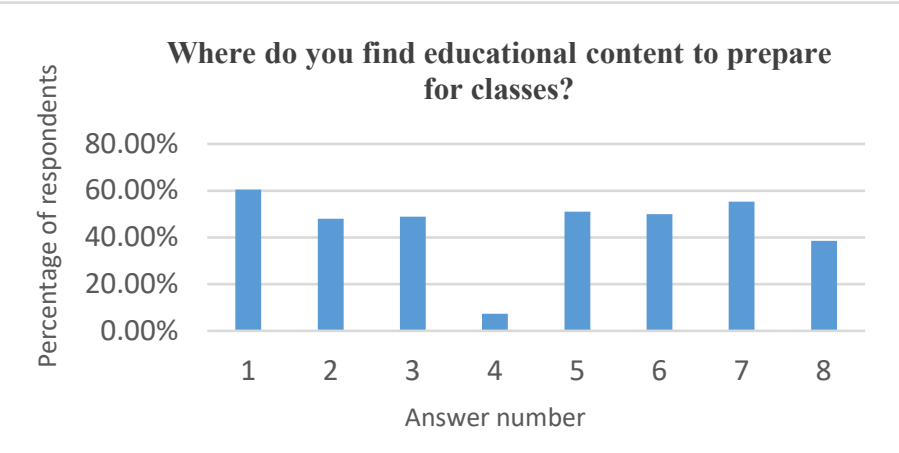

Figure 3: Students' answers to the question: "Where do you find educational content to prepare for classes?"

Answer options:

[1] I use summary of lectures or seminars

[2] I use an educational content recommended by a teacher
[3] I discuss study questions with other students

[4] I use resources of the university library

[5] I read electronic textbooks

[6] I use e-guides

[7] I read articles on Wikipedia

[8] I use specialized forums

Elements of informal learning are changing the traditional educational process of IT-students in such aspects as the source of knowledge, personalization, teaching/learning methods and teacher activities [14].

We can see from histogram in Figure 3 students' answers to the question: "Where do you find educational content to prepare for classes?" [14].

Survey shows, that students use the summaries of lectures or seminars and educational content, recommended by a teacher in educational process as often as electronic educational resources: electronic textbooks, e-guides, specialized forums. They use Wikipedia often, but only $7 \%$ of students tend to use resources of the university library.

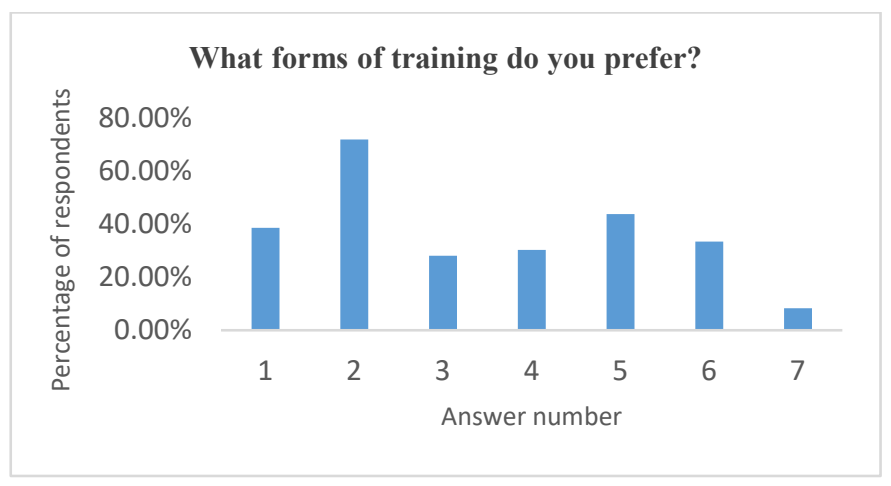

Figure 4: Students' answers to the question: "What forms of training do you prefer?'

Answer options:

[1] Traditional lectures and classroom workshops

[2] Project work in a small group

[3] Independent work outside the classroom

[4] Solving individual tasks

[5] Independent development of software applications

[6] The solution of creative tasks without ready-made solutions

[7] Other

Students give preferences to forms of training, relevant for informal learning in frames of traditional educational process. We can see from histogram in Figure 4 students' answers to the question: "What forms of training do you prefer?"[14].

Histogram shows that students prefer learning interactions (project work) in small groups and implementation of specific learning activities (independent development of software applications) rather, than traditional forms of learning. These forms of training are relevant for informal learning.

Thus, students personalize the sources of educational content, forms and methods of training, place and time of self-directed learning. Studying in formal academic groups, university students actively shape their personal learning environment and try to develop individual learning strategies.

Four factors are changing the activities of teachers: permanent changes in the subject area of education, development of sources of educational information, transformation of the educational 
activities forms of students and formation of EIEE. Obviously, teachers should take into account these factors under developing of teaching strategies.

Teachers can use open educational resources for teaching and create new educational resources in collaboration with students. Web - resources and EIEE allow to restructure information in its accumulation and development, provide the ability to share and edit educational documents [1]. Use of educational and professional web-resources allows teachers to expand the content of IT disciplines, organize collaboration with students, promote the creative educational activities of students and ensure the personalization of learning.

\subsection{Enterprise Infocommunication Infrastructure in Educational Content}

In [23] it is proposed to combine all major engineering disciplines in the Industry 4.0 knowledge areas with their respective functions: "Designing CPS (Cyber Physical Systems), Modularity, Interoperability (Objects, machines and people need to be able to communicate through the Internet of Things and the Internet of People), Virtualization, Decentralization, Real-Time Capability, Service-Orientation".

Kondakov distinguishes following stages of the educational content formation in the era of fourth industrial revolution [24]:

- Pre-subject stage includes development of general theoretical ideas about the structure and composition of educational content, taking into account prospective requests from families, society, state, peculiarities of the educational process organization in accordance with curriculum and with extracurricular activities.

- Subject stage includes definition of composition of academic disciplines, their content and allocation by educational levels.

- Development of educational materials.

- Organization of teaching/learning strategies.

- Stage of assignment by students of new educational content, forms and types of activities, skills and competencies.

Every stage is considered further based on our experience in teaching of IT-disciplines.

\subsubsection{Pre-subject Stage of Formation of Educational Content}

At the pre-subject stage of formation of educational content of IT-stidents, it should be borne in mind that modern enterprises have a permanently developing complex infocommunication infrastructure. Specialists in such infrastructure have to work in the network environment, they must be proficient in network technologies and enterprise information systems [16].

Enterprises use information technologies in different areas of their functioning: the business-processes automation, support of collaboration with partners, the electronic document flow management etc. Structure of the enterprise IT-department is built as a system of the processes managing services. This serviceoriented structure allows management of IT-department to provide high quality services and efficient business solutions for an enterprise. IT-department provides services to functional departments, and connections between them are based on the "provider - consumer" model. Functional departments set their requirements for the services of specified types and their quality. Infocommunication infrastructure is supported and developed by IT-departments according to required services and set quality. Thus the enterprise IT-department is an important resource for the enterprise management system. Table 3 shows the hierarchy of enterprise management levels and basic management functions corresponding to each level.

Table 3: Hierarchy of the Enterprise Management Levels

\begin{tabular}{|l|l|}
\hline \multicolumn{1}{|c|}{$\begin{array}{c}\text { Level of enterprise } \\
\text { management }\end{array}$} & \multicolumn{1}{c|}{ Functions } \\
\hline $\begin{array}{l}\text { Financial and economic } \\
\text { activity }\end{array}$ & $\begin{array}{l}\text { Financial planning, customer } \\
\text { relationship, supply chain, } \\
\text { human resources, etc. }\end{array}$ \\
\hline Production activities & $\begin{array}{l}\text { Operational planning, quality } \\
\text { management, order deadlines } \\
\text { control, productivity control, } \\
\text { etc. }\end{array}$ \\
\hline Manufacture management & $\begin{array}{l}\text { Technological processes, } \\
\text { production processes }\end{array}$ \\
\hline Industrial controllers & Data collection, data processing \\
\hline Sensors & $\begin{array}{l}\text { Scanning of sensors, operating } \\
\text { mechanisms }\end{array}$ \\
\hline
\end{tabular}

Each level performs specific management functions and uses its own computing network environment. The lowest level is sensory. At this level, a network of sensors and of various actuating mechanisms is implemented. In the context of the development of Industry 4.0, sensors will be the basis for the development of the Internet of Things [25]. The level of industrial controllers is implemented by the controller network. The industrial and office local networks are used at the manufacture management level. The local or the enterprise office networks are used at the production management levels and at the levels of financial and of economic activities of an enterprise.

The information networks have specific characteristics of functioning at every management level. The network infrastructure management must be considered during training of IT-students.

\subsubsection{Subject Stage of Formation of Educational Content}

At the subject stage, we offer teaching of several disciplines within the curriculum on an interdisciplinary basis as one of the educational approaches to the formation of educational content of IT- students.

A hierarchical model of enterprise architecture can be a basis for interdisciplinary connections in the professional training of ITstudents. Enterprise architecture includes structured description of document flow and business processes of an enterprise, applications and automation methods that support business processes, as well as information, technology and infrastructure.

Table 4 shows levels of enterprise architecture in accordance with model TOGAF (The Open Group Architecture Framework) [17], their components and disciplines for training of IT-students. 
Table 4: Disciplines for Training of IT-students in Accordance with TOGAF Model

\begin{tabular}{|l|l|l|}
\hline $\begin{array}{l}\text { Enterprise } \\
\text { architecture } \\
\text { levels }\end{array}$ & $\begin{array}{l}\text { Components of } \\
\text { enterprise } \\
\text { information systems } \\
\text { architecture }\end{array}$ & $\begin{array}{l}\text { Disciplines for } \\
\text { training of IT- } \\
\text { students }\end{array}$ \\
\hline $\begin{array}{l}\text { Business } \\
\text { architecture } \\
\text { applications }\end{array}$ & $\begin{array}{l}\text { Information systems } \\
\text { design. } \\
\text { Enterprise } \\
\text { information systems }\end{array}$ \\
\hline $\begin{array}{l}\text { Application } \\
\text { architecture }\end{array}$ & $\begin{array}{l}\text { Enterprise } \\
\text { information systems }\end{array}$ & $\begin{array}{l}\text { Information systems } \\
\text { design. } \\
\text { Enterprise } \\
\text { information systems }\end{array}$ \\
\hline $\begin{array}{l}\text { Data } \\
\text { architecture }\end{array}$ & $\begin{array}{l}\text { Physical data stores, } \\
\text { data management } \\
\text { tools, } \\
\text { logical and physical } \\
\text { data models }\end{array}$ & $\begin{array}{l}\text { Database. } \\
\text { Database } \\
\text { management } \\
\text { systems. } \\
\text { Enterprise } \\
\text { information systems }\end{array}$ \\
\hline $\begin{array}{l}\text { Technological } \\
\text { architecture }\end{array}$ & $\begin{array}{l}\text { Infocommunication } \\
\text { infrastructure }\end{array}$ & $\begin{array}{l}\text { Infocommunication } \\
\text { systems and } \\
\text { networks. } \\
\text { Network } \\
\text { technologies. } \\
\text { Information security }\end{array}$ \\
\hline
\end{tabular}

Content of studied disciplines is defined by the enterprise architecture type. Its own network computing environment with own characteristics of functioning corresponds to each hierarchical level of infrastructure. In training of IT-students, attention should be paid to the management of information network infrastructure [16].

\subsubsection{Creation of Educational Materials}

As noted above, knowledge related to the elements of Industry 4.0 include: networks, information technologies, interfaces and communication protocols, understanding of systems, sensors and electronics. The composition of IT disciplines can be formed in accordance with the enterprise infocommunication infrastructure. To study disciplines in which the information network environment is considered, students have to acquire next basic knowledges:

- distributed computing; distributed information-processing system;

- basic networking concepts;

- the cable and wireless technologies in local and enterprise networks; networking standards; communication interfaces;

- data communications technologies; data access, coding of signals and data;

- network services;

- life cycle management of an enterprise; service-oriented computing of business processes;

- the system development life cycle; functional subsystems of an enterprise.

\subsubsection{Organization of teaching/learning strategies}

An interdisciplinary approach to teaching allows organizing the following forms of learning activities of IT students:

- Creation of infrastructure of local network on real computers as practical activities. Students are invited to install the cable network, computers and communication hardware, they have to set up and test of elements of infocommunication system and network.

- Each student invited to create a virtual environment on his/her real machine to master the administration of networks. Next step is creation a virtual environment that includes a server and one (or more) networked workstations. After creating the virtual environment, the student should master the skills of configuring different network services.

- In order to master the formation and configuration of the complex services parameters, students should study the setup of terminal access, methods of organizing of the secure data transmission tunnels, the formation of help services and other issues of the enterprise infrastructure management.

\subsubsection{Assignment of new educational content, forms and types of} activities, skills and competencies by students

The rapid transformation of the professional environment of IT specialists requires constant updating of the content of professional disciplines. Forms and methods of teaching / learning are developing in accordance with the updating of educational content.

In our teaching activities, we constantly update the content of the taught disciplines in accordance with the development of information systems and network technologies in enterprises (e.g. [17]-[19]).

Feedback. Kazan National Research Technical University annually holds meetings of students with representatives of enterprises, and often our graduates are representatives of enterprises. Discussion of our approach to the formation of educational content and to forms of practical classes with students and alumni shows:

- the topics covered in this paper seem extremely interesting to them;

- students are interested in practical applications of technologies that they get acquainted with in classrooms;

- forms of practical classes are especially fascinating for students.

\section{Conclusion}

According to [6], it is too early to draw conclusions about the long-term impact of the global pandemic on education, and emergency online teaching should not be equated with pedagogically effective online teaching in accordance with the needs of students and potential employers. But it is clear, that coronavirus pandemic and rapid transition to distance learning significantly accelerated an introduction of Education 3.0 - 4.0 technologies into traditional educational process.

Development of e-learning methods takes place on this basis, and these methods are actively applied by the pedagogical community in modern situation. Introduction of e-learning technologies leads to development of EIEE of educational 
institutions and to active development of personal-oriented EIEE of students. All these aspects of advanced learning are realized by students through educational self-organization in traditional educational process.

The results of the survey of IT students presented in this paper show that they independently use such technologies of Education 4.0 as mobile learning, self-directed learning and informal learning. The survey results are consistent with our teaching experience. These processes contribute to the 'learning to learn' meta-competence formation and to preparation of students for lifelong learning in context of fourth industrial revolution.

Teachers need to perform the following activities in modern conditions [13]: participation in the continuous development of the EIEE of educational institution in collaboration with students; constant updating of the educational content of disciplines, which should include interdisciplinary educational content; developing teaching/learning strategies in accordance with the state of the professional environment of modern specialists.

For developing educational content in teaching IT students, we propose to use the enterprise infocommunication infrastructure as the system-forming factor. Professional activities in the conditions of permanent development of the infocommunication infrastructure of modern enterprises requires specialists to master enterprise information systems and their network environment. Teaching on an interdisciplinary basis can be considered as one of the perspective approaches to training of such specialists. Our experience shows that this approach allows to update the necessary educational content and teaching/ learning strategies in accordance with the development of the professional environment of IT professionals in modern conditions.

Table 5 shows, what possible teaching/learning strategies in context of Education 4.0 can be used for formation of competencies of Industry 4.0.

Table 5: Teaching/learning Strategies of Education 4.0 for Formation of Competencies of Industry 4.0

\begin{tabular}{|l|l|}
\hline $\begin{array}{l}\text { Competencies of Industry } \\
4.0\end{array}$ & $\begin{array}{l}\text { Teaching/learning strategies in } \\
\text { context of Education 4.0 }\end{array}$ \\
\hline Lifelong learning & Informal learning \\
\hline Self-directed learning & $\begin{array}{l}\text { Mobile learning. } \\
\text { Personally-oriented EIEE of } \\
\text { students }\end{array}$ \\
\hline Programming & $\begin{array}{l}\text { Informal learning. } \\
\text { Mobile learning. } \\
\text { Personally-oriented EIEE of } \\
\text { students }\end{array}$ \\
\hline $\begin{array}{l}\text { Technical skills; } \\
\text { information technologies; } \\
\text { process understanding }\end{array}$ & $\begin{array}{l}\text { Teaching on an interdisciplinary } \\
\text { basis }\end{array}$ \\
\hline $\begin{array}{l}\text { Data communications } \\
\text { and networks; } \\
\text { interfaces and } \\
\text { communication } \\
\text { protocols; understanding } \\
\text { of systems; } \\
\text { understanding IT security }\end{array}$ & $\begin{array}{l}\text { Teaching on an interdisciplinary } \\
\text { basis. } \\
\text { Enterprise infocommunication } \\
\text { infrastructure, as the system- } \\
\text { forming factor of educational } \\
\text { content }\end{array}$ \\
\hline
\end{tabular}

\section{Conflict of Interest}

The authors declare no conflict of interest.

\section{Acknowledgment}

The authors are grateful to colleagues for the expert assessment and useful discussion of our work. The authors would like to thank Ekaterina Golitsyna for help in writing and redaction of the paper text.

\section{References}

[1] I.N. Golitsyna, F.I. Eminov, B.F. Eminov, "Education 4.0 in teaching/learning strategies," in Proceedings - International Conference on Developments in eSystems Engineering, DeSE, 2019, doi:10.1109/DeSE.2019.00046.

[2] M. Klonn, J. Abke, “'Learning 4.0': A Conceptual Discussion,” in Proceedings of 2018 IEEE International Conference on Teaching, Assessment, and Learning for Engineering, TALE 2018, 2019, doi:10.1109/TALE.2018.8615244.

[3] M. Hernandez-de-Menendez, R. Morales-Menendez, C.A. Escobar, M. McGovern, "Competencies for Industry 4.0," International Journal on Interactive Design and Manufacturing, 14(4), 1511-1524, 2020, doi: 10.1007/s12008-020-00716-2.

[4] S. Poloskov, A. Zheltenkov, I. Braga, I. Kuznetsova, "Adaptation of hightech knowledge-intensive enterprises to the challenges of industry 4.0," E3S Web of Conferences, 210, 1-10, 2020, doi:10.1051/e3sconf/202021013026.

[5] M.T.A. Jima'ain, F.N.A. Hassan, K.A. Razak, A. Hehsan, J. Junaidi, "The emerging challenges of industrial revolution 4.0: A students' perspective," International Journal of Advanced Science and Technology, 29(6), 12151225,2020

[6] L.M. Kipper, S. Iepsen, A.J. Dal Forno, R. Frozza, L. Furstenau, J. Agnes, D. Cossul, "Scientific mapping to identify competencies required by industry 4.0," Technology in Society, 64(October 2020), 2021, doi:10.1016/j.techsoc.2020.101454.

[7] W. Maisiri, H. Darwish, L. van Dyk, "An investigation of industry 4.0 skills requirements," South African Journal of Industrial Engineering, 30(3), 90 105, 2019, doi:10.7166/30-3-2230.

[8] C. Demartini, L. Benussi, "Do Web 4.0 and Industry 4.0 Imply Education X.0?,”IT Professional, 19(3), 4-7, 2017, doi:10.1109/MITP.2017.47.

[9] P. Kowalikova, P. Polak, R. Rakowski, "The Challenges of Defining the Term 'Industry 4.0,"' Society, 57(6), 631-636, 2020, doi:10.1007/s12115020-00555-7

[10] C.A. Bonfield, M. Salter, A. Longmuir, M. Benson, C. Adachi, "Transformation or evolution?: Education 4.0, teaching and learning in the digital age," Higher Education Pedagogies, 5(1), 223-246, 2020, doi:10.1080/23752696.2020.1816847.

[11] F.J. GARCÍA-GARCÍA, E.E. MOCTEZUMA-RAMÍREZ, T. YURÉN, "Learning to learn in universities 4.0. Human obsolescence and short-term change," Teoria de La Educacion, 33(1), 221-241, 2021, doi:10.14201/TERI.23548.

[12] H. Sulaiman, N. Suid, A.B.I. Mohd, "Usability Evaluation of Confirm-A Learning Tool Towards Education 4.0," in 2018 IEEE Conference on eLearning, e-Management and e-Services, IC3e 2018, 2019, doi:10.1109/IC3e.2018.8632637.

[13] I.N. Golitsyna, "[Education 4.0 in the training of modern specialists]," Mezhdunarodnyy Elektronnyy Zhurnal “Obrazovatel'nyye Tekhnologii i Obshchestvo (Educational Technology \& Society)“, 23(1), 12-19, 2020. (In Russ., abstract in Eng.).

[14] I.N. Golitsyna, "Informal Learning in the Educational Process of IT Professionals," in 5th International Conference on Lifelong Education and Leadership for all, Conference Proceeding Book, 93-98, 2019.

[15] I.N. Golitsyna, "[Informal learning as a part of modern educational process]," Mezhdunarodnyy Elektronnyy Zhurnal “Obrazovatel'nyye Tekhnologii i Obshchestvo [Educational Technology \& Society] “, 21(4), 344-350, 2018. (In Russ., abstract in Eng.).

[16] F.I. Eminov, I.N. Golitsyna, B.F. Eminov, "Enterprise infocommunication infrastructure in training of IT-professionals," in Journal of Physics: Conference Series, 2018, doi:10.1088/1742-6596/1015/4/042014.

[17] F.I. Eminov, Information technologies of enterprises management, Master Line, Kazan, 2015. (In Russ.). 
[18] B.F. Eminov, F.I. Eminov, Enterprice infomation systems. Study guide. Ministry of Science and Higher Education of the Russian Federation; Kazan National Research Technical University named after A.N. Tupolev, Kazan State Technical University, Kazan, 2019. (In Russ.).

[19] B.F. Eminov, F.I. Eminov, Network technologies. Study guide, KNITU-KAI, Kazan, 2019. (In Russ.).

[20] R.A. Karim, A. Ghani, B. Abu, A. Haimi, M. Adnan, A. Dwi, J. Suhandoko, L. Studies, U.T. Mara, P. Branch, T. Campus, T. Road, "The use of mobile technology in promoting education 4.0 for higher education," Advanced Journal of Technical and Vocational Education, 2(3), 34-39, 2018, doi:10.26666/rmp.ajtve.2018.3.6.

[21] I.N. Golitsyna, "[Flexible learning in a traditional educational process]," Vysshee Obrazovanie v Rossii [Higher Education in Russia], (5), 113-117, 2017. (In Russ., abstract in Eng.).

[22] T. Wanner, E. Palmer, "Personalising learning: Exploring student and teacher perceptions about flexible learning and assessment in a flipped university course," Computers and Education, 88, 2015, doi:10.1016/j.compedu.2015.07.008.

[23] L. Jeganathan, A.N. Khan, J. Kannan Raju, S. Narayanasamy, "On a frame work of curriculum for engineering education 4.0," in 2018 World Engineering Education Forum - Global Engineering Deans Council, WEEFGEDC 2018, 2019, doi:10.1109/WEEF-GEDC.2018.8629629.

[24] A. Kondakov, [School of the era of the fourth industrial revolution], 2017. (In Russ.). 